\title{
Debatforum: \\ Ernst Triers Grundtvigresepsjon: Om dannelse og yrkesutdanning i Vallekilde
}

\author{
Av Pål Bødtker Walstad
}

I Grundtvig-Studier 2006 (se også denne udgave, s. 236) har Ove Korsgaard en betimelig artikkel om "Hvordan erindres folkehøjskolens historie?" der han beskriver den opprinnelige motsetning mellom dansk og latinsk dannelse og senere motsetninger mellom dannelse og yrkesutdanning og nåtidens sammenblanding av opprinnelige og senere motsetninger. I motsetningen mellom dannelse og yrkesutdanning la de såkalt "riktige" høyskoler vekt på dannelse, og de såkalt "urene" høyskoler inkluderte yrkesrettede utdanninger. I spørsmålet om hvordan erindre folkehøyskolens historie, har Grundtvigetterfølgeren Ernst Trier gitt verdifulle bidrag. Denne artikkelens hensikt er å gi en stemme til pioneren Ernst Trier som har vist at praktisk arbeid og yrkesutdanning var inkludert i Grundtvigs folkelige dannelse.

\section{Vallekilde Folkehøjskole}

Teologen Ernst Johannes Trier (1837-93) startet på Grundtvigs oppfordring Vallekilde Folkehøjskole i det nordvestre Sjælland i 1865. Som de fleste andre høyskoler på den tiden, fungerte skolen som en "Bondehøjskole". Den betegnelsen passet godt siden Trier hadde stor interesse for landbruket og sørget for at en betydelig avlsgård hørte til skolen, men betegnelsen "Folkehøjskole" ble i 1867 gjort gjeldende for denne og tilsvarende skoler. Sammen med støttespillere som skreddersvennen Jens Pedersen, presten Villiam Johannes Hoff, hjulmannen Niels Pedersen, læreren Peder Tranberg, bonden og folketingsmannen Niels Jokum Termansen, forfatteren Anton Nielsen og byggmester, lærer Andreas Bentsen og andre utviklet han høyskolen i Vallekilde til å omfatte en rekke yrkesutdanninger som alle hørte inn under Triers folkehøyskole. Skolen bidro til å heve håndverkerstanden i Danmark, og eksempelvis bidro Andreas Bentsen til å utdanne ca. 3000 håndverkere i løpet av sine ca. 30 år ved Vallekilde Folkehøjskole. Fellesfagene var dannelsesfagene morsmål og historie, men et særkjenne ved skolen var at den i tillegg til de nasjonale dannelsesfagene omfattet praktisk-estetiske fag som gymnastikk, forming og kunsthåndverk og utdanninger for yrker innen landbruk, sjøfart og fiske, innen håndverk og kunstmaling.

I 1884 ble den svenske gymnastikken, utviklet av Pehr Henrik Ling, innført ved skolen, og denne gymnastikken ble toneangivende for den grundtvigske legemskulturen. (Korsgaard 1982/97, 82). Denne 
gymnastikken hadde et naturvitenskapelig grunnlag $\mathrm{i}$ anatomi og fysiologi og et åndsvitenskapelig grunnlag i diktning, historie og estetikk. Andre praktisk-estetiske fag som kunst og kunsthåndverk fikk også plass i Vallekilde. Under oppveksten og studietiden hadde Ernst Trier hyppig kontakt med kunstnervenner. Musikeren og komponisten Emil Hartmann, pianisten August Winding og billedhuggerne Karl Hartmann og Christian Schierbeck hørte med til vennekretsen. Derfor fikk estetikken en sentral plass ved skolen, men høyskoleforstanderen Ernst Trier hadde sans for estetikk på en annen måte enn studenten. Estetiske verdier ble hos høyskoleforstanderen avgrenset til å tjene skolens hensikt. Betegnende er derfor maleren Christen Dalsgaards bilde av Nordens apostel, benediktinermunken "Ansgar der døber". Bildet ble strategisk plassert i foredragssalen. Møtet mellom det danske folk og kristendommen, det nasjonale og det kristelige, var viktig i skolens målsetting.

Det allmennfaglige, praktisk-estetiske og yrkesrettede var hos Trier vevet sammen i én, helhetlig folkelig dannelse. Den var folkelig ved at den var utviklet "nedenfra", den stettet behov i lokalbefolkningen og fremmet nasjonal gjenreisning etter nederlaget i 1864 . Støttespillerne i Vallekilde hadde tilknytning til kirken eller lavkirkelige, gudelige forsamlinger, og de hadde variert yrkesmessig bakgrunn. Sammen representerte de Vallekilde Folkehøjskoles spennvidde fra det folkelig/nasjonale og kristelige til estetikk og arbeidsliv (Walstad 2006, kap. 4).

\section{Trier og Grundtvig}

Ernst Triers forhold til Grundtvig må karakteriseres som svært nært. Trier var en engasjert og ivrig personlighet, derfor ofte kalt "Iver Iversen", og ingen ivret mer enn han etter å være i kontakt med Grundtvig. Blant Grundtvigs etterfølgere og blant studentvennene i "lille Theologicum" var Trier Grundtvigs mest fortrolige. I skriftet "Erindringer fra Grundtvigs hjem" forteller Trier at han fra og med 1859 pleiet hyppig kontakt med Grundtvig:

ti fra den tid kom jeg ikke sjælden til ham; var der spørgsmål, hvorover jeg havde ondt ved at få klarhed, tyede jeg altid til ham. Har jeg lært meget ved hans prædiken og hans skrift, synes jeg dog at have făet endnu mer ved samtaler med ham (Trier 1883/1911,65).

Under Triers studietid dreiet samtalene seg ofte om dogmatikk, eksegese og kirkehistorie, men etter at Trier startet Vallekilde Folkehøjskole, handlet samtalene også om skolespørsmål: 
Med stor deltagelse fulgte han skolens udvikling her de følgende år. Sikker var jeg altid på hos ham at kunne få et godt råd og et godt ord, der hjalp til at holde frimodigheden oppe (ibid. 72).

Med Trier som aktiv tilhører og deltager kunne samtalene strekke seg over to til tre timer, men Trier ble ikke trett. Snarere tvert imot. I et brev til Marie Abel skriver Trier at "jeg ordentlig pumpede den gamle!" (Hansen 1933, 82). Når Trier skriver at samtalene dreiet seg om morsmålet, den danske grunnlov, jordbeskrivelse og gudsbilledet, fikk Trier viktige signaler for sin skolevirksomhet. Det nasjonale, det yrkesrettede og det kristelige ble karakteristisk for høyskolen i Vallekilde.

Gjennom samtalene og lesning av Grundtvigs pedagogiske skrifter fra og med Nordens Mythologi (1832) har sannsynligvis Trier fått forståelse av at det yrkesrettede var del av Grundtvigs dannelsestenkning. I innledningen til $N M$ ivaretas det yrkesrettede når Grundtvig ønsket å opprette en "høiere Anstalt for folkelig Dannelse og for praktisk Duelighed i alle Hoved-Fag" (GSkv I, 240). Yrkesrettede perspektiver er også tydelige i Statsmoessig Oplysning (1834). Her bekreftet Grundtvig at hans akademi vil utdanne lærere, prester, jurister og dessuten militært personell (Grundtvig 1834/1983, 55 ff.). I skoleskriftene som utkom på rekke og rad fra og med 1836, er den folkelige dannelse for alle, og Grundtvig er i disse skriftene mindre konkret om det yrkesrettede og mer åpen for at folk selv skulle gi innhold til den folkelige dannelse, nettopp for at den skulle kunne være folkelig. Men også i disse skriftene er det yrkesrettede med. I skoleskriftet Til Nordmoend om en Norsk Høi-Skole (1837) formulerte Grundtvig en målsetting om at

vi maae ønske dem en Dannelse og Oplysning, der giør dem dueligere til deres Dont og lykkeligere i deres Stilling, eller vi er splittergale, og ønske at giøre baade dem og os selv ulykkelige, til Ære for et tomt Hjerne-Spind, vi kalde Oplysning og Dannelse (GSkv II, 72).

Legg merke til de friske formuleringer om dannelse og opplysning uten yrkesrettede mål. Det viktigste innholdet var imidlertid morsmålet som Grundtvig i skoleskriftet Den Danske Høiskole (1847) betegnet som "Hovedsagen" (GSkv II, 241f.). Men i tillegg til nasjonale dannelsesfag ønsket Grundtvig et bredere innhold. I Til Nordmoend om en Norsk Høi-Skole sammenfattet han innholdet slik: "Folkets og Landets og Moders-Maalets Natur og Beskaffenhed, nærværende Tilstand og naturlige Forbedring og Fremgang" som han igjen sammenfattet i det åpne og uferdige uttrykket "Livets Gavn og Landets Tarv" (GSkv II, 68 og 71). Det er slike upresise og uferdige uttrykk, samt uttrykk som "Livets Tarv", "Livet, som det virkelig er" og livets "Brugbarhed" fra $N M$, som Trier gjør presise når han og hans 
støttespillere realiserer dem som dannelse og yrkesutdanning i Vallekilde (GSkv II, 91).

Til tross for at Grundtvigs omtale av det yrkesrettede skjer på en mindre presis måte i skoleskriftene enn i $N M$ og i Statsmoessig Oplysning, lar han det likevel på forskjellig vis skinne igjennom at det å beherske det praktiske arbeidet $\mathrm{i}$ et yrke, er en del av et menneskes dannelse. Ved at han tok sine sønner Johan og Svend ut av latinskolen, ga dem hjemmeundervisning i lesning, skrivning, regning, historie, geografi og litt gresk og satte dem til å lære det praktiske arbeidet i bokbinder- og snekkeryrket, viser han indirekte til et pedagogisk landskap der drengeskolen er nedlagt og erstattet av verksteder. Men et slikt pedagogisk landskap nevner han direkte i de fire kjente skoleskriftene Det Danske Fiir-Kløver (1836), Til Nordmaend om en Norsk Høi-Skole (1837), Skolen for Livet (1838) og Om Nordens videnskabelige Forening (1839) (GSkv II, 31; GSkv II, 72; GSkv II, 102; GSkv II, 154). I førstnevnte skrift sier han:

Den eneste gode Drenge-Skole for Borger-Livet, jeg har nogen Forestilling om, er dygtige og driftige Borgeres Huse, hvor Drengene kan faae baade Lyst til Syslerne, de siden skal drive og Greb paa dem (GSkv II, 31).

Dette pedagogiske landskapet er imidlertid for barn og ungdom under atten år. Når de er atten år og kan begynne på en høyskole, har Grundtvig i skoleskriftet Den Danske Høiskole (1847) også skissert et pedagogisk landskap:

At man ved Siden ad den Danske Høiskole drev en Avlsgaard udmorket godt, det vilde vistnok baade være fornøieligt og gavnligt, og hvis Høiskolen var omringet af Varksteder, hvor alle Haandvorker dreves udmoerket godt, da vilde baade Fornøielsen og Gavnligheden være udmarket stor (GSkv II, 254).

Tanken synes å være at de som behersket det praktiske arbeidet i et yrke før de kom til høyskolen, fikk anledning til videreutdanning, og de som manglet slik grnnnopplæring, skulle få anledning til nettopp slik opplæring. Det er dette grundtvigsk-pedagogiske landskapet med et akademi omgitt av gårdsbruk og verksteder Ernst Trier virkeliggjorde, og få eller ingen har gjort det så tydelig som han.

\section{Menneskesynet}

Kort tid etter at Trier hadde avlagt teologisk embetseksamen i 1863, skulle han begynne som lærer i bibelhistorie ved Tangs seminar på Blaagaard. Lese- og eksamenstrett og sannsynligvis rådvill tok han 
kontakt med Grundtvig for å få noen gode råd i sin første lærerstilling, men Grundtvig ga ham langt mer:

Efter en kort betænkningtid gav han mig nemlig i stor oversigt en hel indledning til bibelhistorien. I spidsen for denne stillede han den mosaisk-kristelige betragtning af mennesket som skabningen, skabt $\mathrm{i}$ Guds billede - falden i synd - bestemt til genoprejsning, og med al den vægt, der lå i hans ord, indpræntede han mig den dag, at det er den oplysning, der må lægges til grund for al ægte og sand folkeoplysning (Trier 1883/1911, 71).

Dette menneskesynet, som Grundtvig tydelig proklamerte allerede i $N M$ og knyttet til den mosaisk-kristelige anskuelse, er altså fra første stund grunnlaget for Ernst Triers pedagogiske virksomhet. Det samme menneskesyn er også grunnlaget for hele virksomheten ved Vallekilde Folkehøjskole. Da Trier i 1884 skulle innvie det nye gymnastikk- eller øvelseshuset og faktisk gjøre menneskekroppen til gjenstand for dannelse, nevner han det samme menneskesynet i sin innvielsestale av bygget:

Fra første Færd af har det været ét, der har været den ledende Tanke igjennem hele den Gjerning, der har været udrettet her: den at drage og hjælpe frem det inderste i Mennesket hos Ungdommen, der samles her, at det gudsbilledlige og dermed det ægte menneskelige maa komme til sin Ret, og det i den folkelige Skikkelse, det maa tage her i Danmark (Schrøder 1894, 71. Jfr. også Trier 1895, 62).

Ernst Triers ønske er at hans skole - med sine nasjonale dannelsesfag, praktisk-estetiske og yrkesrettede virksomheter - skal imøtekomme det gudbilledlige og ekte menneskelige i hver enkelt elev. Triers gode venn Ludvig Schrøder forteller at

Trier kunde se det gudbilledlige hos Mennesket, ogsaa hvor det var stærkest formørket, og det var Maalet for hans Virksomhed at faa dette lysende, straalende, gudbilledlige til at overvinde Mørket, som skjulte det. Det gudbilledlige er Kongsmærket, og hvor det kommer frem, vil det ogsaa vise sig, at hver enkelt Personlighed har sit særegne Livskald (Schrøder 1904, 246).

"Den ledende Tanke" hos Ernst Trier var at menneskets gudbilledlighet skulle ha vekstvilkår. Hans skole for livet kunne ikke avgrenses til fritidslivet eller bare deler av livet, men omfatte hele menneskelivet, også arbeidslivet, for bare slik kunne elevenes livskall ivaretas.

At høyskolen skulle baseres på det menneskesyn at mennesket var skapt i Guds bilde, var tydelig i den mosaisk-kristelige anskuelse som Grundtvig proklamerte i NM. I samme skrift var det yrkesrettede "i alle det Praktiske Livs Hoved-Retninger" del av dannelsen (GSkv I, 
241). Også senere bekrefter Grundtvig menneskesynets avgjørende betydning for høyskolens innhold. I en Marienlysttale i 1862 sier han i forlengelsen av at mennesket er "et ganske eget, forunderlig Slags levende Skabninger i Guds Billede" at elevene må "faae at vide, baade hvad Menneske-Livet duer til, og hvordan de bedst kan bruge den Lodd og Deel, de har i Menneske-Livet, til Gavn og Glæde baade for dem selv og for hverandre" (Grundtvig 1956, 61). Kanskje har ikke Trier lest eller hørt om denne talen og kanskje heller ikke snakket med Grundtvig om den, men det er denne tanken Trier har som sin "ledende Tanke" i Vallekilde. Hans skole skulle være slik innrettet at den ga unike og gudbilledlige elever muligheter til å "bruge den Lodd og Deel, de har i Menneske-Livet", inklusive arbeidslivet.

\section{Vekkelses- og vekstskole}

Helge Grell gir i boken Vision og virkeliggørelse (1998) Vallekilde Folkehøjskole karakteristikken vekkelsesskole. Det er det gode grunner for. I 1877 karakteriserte Ministeriets tilsynsmann, Mathias Stenstrup, Triers skole ikke som en kunnskapsskole, men som en "Vækkelsesskole i koldsk Ånd, med Vægten på det kristelige" (M. Thomsen 1982, 41). Kunnskap hørte med, men viktigere var vekkelse. På samme måte som Christen Kold gjennom sine skoler ønsket å fremme og vekke tro på "Guds Kærlighed og Danmarks Lykke" (Berntsen 1913, 25), ønsket Trier å fremme både en nasjonal og kristelig vekkelse. Han ønsket å "bygge det ny hus op i Danmark i læ af Vor Herre Jesu Kristi menighed, Guds vingers skygge" (Trier 1893, 112), og han håpet at "den oplysning og dannelse, jeg vilde føre frem, kun skulde bidrage til at lære os bedre at bøje knæ for Jesus Kristus Vor Herre, så den skulde være en ydmyg tjenerinde over for Guds menighed og dens sag" (Trier 1893, 32). At den kristelige vekkelse sto sterkt hos Trier, hadde både Mathias Stenstrup og Helge Grell rett i.

Men Vallekilde Folkehøjskole var noe mer enn en vekkelsesskole. Hovedtanken eller "den ledende Tanke" bak fagene og virksomhetene var å gi vekst til den enkeltes personlighet og potensialer slik at det ekte menneskelige, det gudbilledlige i den enkelte elev, kunne vokse. Slik vekst var ikke avgrenset til bønder og landbruk, men gjaldt alle elevene. Skolens formidable oppgave ble å "matche" den enkeltes unikhet. "Skolen for Livet" ble av Trier tolket som en skole for hele menneskelivet, også arbeidslivet, for bare slik kunne elevenes livskall prøves ut. Grundtvig beskrev mennesket i den mosaisk-kristelige anskuelse som "et Guddommeligt Experiment" (GSkv I, 239). Ernst Trier satset alle sine eiendeler og penger på dette eksperimentet, i den hensikt å imøtekomme den enkeltes særegenhet og livskall. Ved siden 
av betegnelsen nasjonal og kristelig vekkelsesskole fortjener Triers skole betegnelsen vekstskole, i betydningen "vekstskole for mennesker skapt i Guds bilde".

\section{En lang tradisjon}

Fra filosofen Platon og til vår egen tid går en linje med motsetning mellom kropp og ånd, mellom mindreverdig kroppsarbeid og høyverdig åndsarbeid. Den er vel kjent $\mathrm{i}$ vår vestlige kultur. Men det går også en linje der det praktiske og kroppslige arbeid er del av et menneskes dannelse. Den er mindre kjent og utbredt, likevel har den en lang historie.

Den jødisk-kristne tradisjon, som Trier hadde et nært forhold til, har et handlingsrettet fromhetsideal. I Salomos ordspråk, med sine eldste deler som går tilbake til kong Salomo (ca. 960-922 f.Kr.), settes arbeid og latskap opp mot hverandre: "Den som er lat i sitt arbeid, er en bror av ham som ødelegger" (Ordspråkene 18,9). Alle skulle bidra til fellesskapet gjennom arbeid. Også de jødiske rabbier. Ved siden av å studere og undervise om hellige skrifter skulle rabbiene utføre et håndverk og brødfø seg og sin familie gjennom det kroppslige arbeidet. Å kunne et yrke, kunne leve av det og lære opp neste generasjon, var del av oppdragelsen. Snekkersønnen Jesus og teltmakeren Paulus tilhørte denne tradisjonen. Hos kirkefaderen Ireneus (125-202), som Grundtvig utviste stor og vedvarende interesse for, var det kroppslige fremhevet som noe godt og gudskapt, og mennesket var skapt som "imago et similitudo dei", Guds bilde og likhet. Hos Benedikt av Nursia (480-547), som Grundtvig også utviste stor og vedvarende interesse for, var praktisk arbeid halvparten av dagsverket, ved siden av bønn og skriftlesning. I benediktinerordenen måtte munkene leve av sine henders gjerning for å være Herrens apostler. Tilsvarende var praktisk arbeid og yrkesopplæring del av dannelsen hos Martin Luther i elementærskolen og i den lærde skole. For Luther var ethvert arbeid og yrke et kall, et "Beruf" som man var "beropt" av Vårherre til å utføre.

I tiden mellom Luther og Grundtvig og Trier finnes den samme tanke om praktisk arbeid og yrkesutdanning som del av dannelsen, bl.a. hos opplysningsfilosofene John Locke og Jean-Jacques Rousseau, hos pietisten August Hermann Francke, hos kameralistene Ferdinand Kindermann, Heinrich Philipp Sextro og den danske Blaagaardprofessor Jacob Saxtorph, hos filantropinistene Johann Bernhard Basedow, Friedrich Eberhard von Rochow og de danske lensgrevene Christian Ditlev Frederik Reventlow og Johan Ludvig Reventlow. Selv om nyhumanisten Wilhelm von Humboldt foretok et tydelig skille 
mellom det greske dannelsesideal og praktisk arbeid og yrkesutdanning, har andre nyhumanister som Johann Gottfried Herder, Johann Heinrich Pestalozzi og Johann Wolfgang Goethe praktisk arbeid og yrkesutdanning som del av deres dannelsesideal (Walstad 2006, kap. 2. Jfr. også Markussen 1995 og Nielsen 1986).

Når Grundtvig åpner for at praktisk arbeid og yrkesutdanning er inkludert i den folkelige dannelsen og når Ernst Trier setter døren på vid gap for dette, representerer dette intet nytt. Snarere tvert imot er denne tradisjonen svært gammel, men Trier løfter den frem og tydeliggjør den sammen med sine medhjelpere. Det egenartede ved Triers Grundtvigresepsjon er etter undertegnedes oppfatning de omfattende pedagogiske konsekvenser han trekker av at mennesket er skapt i Guds bilde.

\section{Folkelig dannelse og yrkesutdanning - en motsetning?}

Allerede før Trier og medspillere starter håndverksutdanninger, malerskole og sjøfarts- og fiskeriutdanning i Vallekilde, er samspillet mellom dannelsesfagene, yrkesrettede og praktiske fag tydelig hos Trier. I et brev fra 1870 forteller han hvordan landbruksfag og legemsøvelser er integrert som støttende fag i forhold til dannelsesfagene:

Med sang indledes og sluttes stedse vore foredrag, fortællinger og oplæsninger. Til at støtte dette tjæner ligesom alt andet på skolen øvelse i læsning og skrivning, regning og tegning med dertil hørende landmåling og nivellering så vel som undervisning $\mathrm{i}$ jordbeskrivelse og naturkundskab. Det er jo også klart, at vore elever kan ikke stadig færdes med åndelige ting. Også legemsøvelser bruger vi, at ikke legemet skal synke sammen (Trier 1870/1894, 8).

Etter at styrmann Jørgen Andersen i 1877-78 hadde vært elev i Vallekilde, startet Andersen sjøfarts- og fiskeriutdanning ved skolen. Triers venn Ludvig Schrøder har beskrevet hvordan fagene var integrert i hverandre: Fiskerne hadde egne timer i sine yrkesrettede emner, men startet dagen med fellesgymnastikk med håndverkerne og sjømennene, de var hver dag til stede under fellessamlingen for alle høyskolens elever der forstander Trier holdt foredrag om verdenshistorien og om menneskelivet "isar som det føres $i$ hver enkelt Menneskesjoel med dets Brydninger og Kampe" (Schrøder 1904, 244). Fellessamværet fortsatte under middagen og under ettermiddagsforedragene om Danmarks historie og under aftensmåltidet og under kveldssamlingene der det var litteraturopplesning og foredrag om aktuelle emner (Schrøder 1894; Schrøder 1904, 243 f.). Selvstudier og samtaler mellom elever med ulike faglige interesser hadde faglige 
gevinster, men også mer enn det. Vallekilde Folkehøjskole var kjent for det gode samholdet mellom elevene. Trier hadde tidlig tatt til orde for det han kalte "kærlighedens samliv", og hans erfaring var at "Mine ord slog straks igennem, og forbavsende hurtig kom vi til at leve smukt, kærligt og godt sammen" (Trier 1893, 63). Det sosiale miljøet blomstret. Den sosiale inkludering synes å avspeile den faglige integrering, og forholdet mellom dannelse og yrkesutdanning kan kanskje best beskrives med Grundtvigs egne ord: "Dannelse og Duelighed for Livet, det Menneskelige og Borgerlige" (GSkv I, 238). $\AA$ lese inn en motsetning i dette uttrykket og i Triers Grundtvigresepsjon, kan virke kunstig.

Men hvis man velger å kalle forholdet mellom dannelse og yrkesutdanning en motsetning, vil undertegnede ty til Knud Ejler Løgstrups begrep "forenende motsetning". En ensidig fokusering på dannelse som teoristudium og akademisering, vil lett føre til det Grundtvig kalte "et tomt Hjerne-Spind", løsrevet fra folks liv. En slik ensidighet hvor "hodet løsrives fra kroppen", hadde heller ingen plass hos Trier. Og en ensidig fokusering på matnyttige yrkesutdanninger med eksamener og prøver, har både Grundtvig og Trier tatt avstand fra. I motsetning til liv og død, kjærlighet og hat, sannhet og løgn som ikke er forenlige og hos Løgstrup kalles "adskillende motsetninger", kan dannelse og yrkesutdanning være forenende motsetninger, med vekt på "forenende". Det enes eksistens utelukker ikke det andres, snarere forutsetter det ene det andres eksistens. Det blir en vedvarende spenningstilstand som ikke skal oppheves av et kompromiss eller "minste felles multiplum", men $i$ selve spenningen $i$ foreningen ligger meningen. I det perspektivet kan diskusjonen om dannelse og yrkesutdanning bli en langvarig, sunn og livgivende samtale.

Men dette perspektivet ligger $\mathrm{i}$ forlengelsen av Trier. Hans utgangspunkt var Grundtvigs mosaisk-kristelige anskuelse. På det grunnlaget søkte han å følge "den ledende Tanke" at skolen skulle gi elevene gode vekstvilkår som mennesker skapt i Guds bilde slik at det gudbilledlige, det ekte menneskelige og det særegne livskall kunne komme til sin rett.

\section{Forkortelser}

Gr.-St.: Grundtvig-Studier (1948ff.), København.

GSkv I-II: K.E Bugge (udg.) (1968), Grundtvigs skoleverden i tekster og udkast, bind 1-2, København.

NM: N. F. S. Grundtvig (1832), "Af "Nordens Mythologi"” i GSkv I, 221-248. 


\section{Litteraturliste}

\section{Værker af N. F. S. Grundtvig}

Bugge, K. E. (udg.) (1968), Grundtvigs skoleverden i tekster og udkast, bind 2, København.

Bugge, K. E. og Vilhelm Nielsen (udg.) (1983), N. F. S. Grundtvig, Statsmoessig Oplysning - et udkast om samfund og skole, København.

Johansen, Steen (udg.) (1956), N. F. S. Grundtvig, Taler paa Marielyst Højskole 1856-71, København.

\section{Værker af andre forfattere}

Berntsen, Klaus (1913). Blade i Mindekransen over Højskoleforstander Kristen Kold, Odense.

Grell, Helge (1998), Vision og virkeliggørelse: En redegørelse for Grundtvigs tanker om folkelig oplysning og en folkelig højskole og for forsøget på at virkeliggøre dem, Skrifter udgivet af Grundtvigselskabet, nr. 29, Aarhus.

Hansen, Povl (1933, Højskoleforstander Ernst Trier. En Skildring af Vallekilde Folkehøjskoles grundloggelse og første udvikling, København.

Korsgaard, Ove (1982/97). Kampen om kroppen: Dansk Idrcets historie gennem 200 år, København.

- (2006). "Debatforum: Hvordan erindres folkehøjskolens historie?" i Grundtvig-Studier 2006, København, 210-220.

Markussen, Ingrid (1995), Til Skaberens Are, Statens Tjeneste og Vor Egen Nytte. Pietistiske og kameralistiske idéer bag fremvaksten af en offentlig skole i landdistrikterne i 1700-tallet, Odense.

Nielsen, Mogens (1986), Sløjd. Traek af fagets idehistorie, Dansk Skolesløjds Forlag.

Schrøder, Ludvig (1894), Ernst Trier Bidrag til oplysning om hans levned, Kolding.

—_ (1904), Den Nordiske Folkehøjskole Bidrag til dens historie, Første Halvbind, København.

Thomsen, Mette (1982), Kunsten og folkehøjskolen, København.

Trier, Ernst (1870/1894), "Et brev fra Ernst Trier (til hr. Bezdek 5. januar 1870)" i Fra Vallekilde Folkehøjskole, årg. 1 1894, 5-10

— (1883/1911), "Erindringer fra Grundtvigs hjem" (Tidligere trykt i Hundrede år, et mindeskrift o.s.v. ved F. Rønning, 1893) i Fra Vallekilde Folkehøjskole, årg. 18, 1911, 64-73

- (1893), "Fem og tyve aars skolevirksomhed i Vallekilde" i Hvorledes folkehøjskolen $i$ Vallekilde blev til, Andet Oplag, København. 
— (1895), "Højskoleforstander Ernst Triers Efterladte Papirer" i Udvalg ved Povl Hansen Indledning ved maleren Viggo Pedersen, København.

Walstad, Pål Henning Bødtker (2006), "Dannelse og Duelighed for Livet" i Dannelse og yrkesutdanning i den grundtvigske tradisjon, Dr. polit.-avhandling, Pedagogisk institutt, Norges teknisknaturvitenskapelige universitet, Trondheim. 